\title{
Expression of the eicosapentaenoic acid synthesis gene cluster from Shewanella sp. in a transgenic marine cyanobacterium, Synechococcus sp.
}

\author{
Haruko Takeyama, ${ }^{1}$ Daisuke Takeda, ${ }^{1}$ Kazunaga Yazawa, ${ }^{2}$ \\ Akiko Yamada ${ }^{2}$ and Tadashi Matsunaga' \\ Author for correspondence: Tadashi Matsunaga. Tel: +81423887020 . Fax: +81423857713. \\ e-mail: tmatsuna@cc.taut.ac.jp
}

1 Tokyo University of Agriculture and Technology, Department of Biotechnology, 2-24-16 Naka-cho, Koganei, Tokyo 184, Japan

2 Sagami Chemical Research Center, 4-4-1 NishiOhnuma, Sagamihara, Kanagawa 229, Japan

\begin{abstract}
The eicosapentaenoic acid (EPA) synthesis gene cluster isolated from a marine bacterium, Shewanella putrefaciens strain SCRC-2738, was cloned and expressed in the marine cyanobacterium Synechococcus sp. A broad-host-range cosmid vector, pJRD215 (10.2 kb, Smr Km'), was used to clone a 38 kb insert, PEPA, containing the EPA synthesis gene cluster, creating plasmid pJRDEPA (approx. $48 \mathrm{~kb}$ ). This plasmid was transferred to the cyanobacterial host at a frequency of $2.2 \times 10^{-7}$. Cyanobacterial transconjugants grown at $29^{\circ} \mathrm{C}$ produced $0.12 \mathrm{mg}$ EPA (g dry weight) ${ }^{-1}$, whereas those grown at $23^{\circ} \mathrm{C}$ produced $0.56 \mathrm{mg}$ EPA (g dry weight) ${ }^{-1}$. The yield was further improved to $0.64 \mathrm{mg}$ ( $\mathrm{g}$ dry weight) ${ }^{-1}$ by incubation for $1 \mathrm{~d}$ at $17^{\circ} \mathrm{C}$. This is believed to be the first successful cloning and expression of such a large heterologous gene cluster in a marine cyanobacterium.
\end{abstract}

Keywords: metabolic engineering, marine cyanobacterium, Synechococcus sp., eicosapentaenoic acid (EPA) production, conjugation

\section{INTRODUCTION}

Highly unsaturated fatty acids are receiving attention as useful dietary components. In particular, $\omega-3$ fatty acids such as eicosapentaenoic acid (EPA, C20:5) are known to prevent several human diseases (Needleman et al., 1979; Terano et al., 1984; Abbey et al., 1990). At present, the main source of dietary EPA is marine fish. However, the undesirable fishy flavour which remains throughout the extraction process of EPA can become a problem when large amounts of EPA are added to food. Marine microalgae have been considered as new sources of dietary EPA because of their lack of fish flavours. Although there are many marine eukaryotic microalgae that produce EPA (Viso et al., 1993; Cohen et al., 1995), their low growth rate does not suit industrial EPA production. Marine cyanobacteria do not produce EPA, but they can be cultured at high densities and can grow much faster than eukaryotic microalgae. It was demonstrated that up to $10 \mathrm{~g}$ dry weight $1^{-1}$ of a marine cyanobacterium could be cultured using a photobioreactor (Takano et al., 1992). Molecular genetic

Abbreviation: EPA, eicosapentaenoic acid. engineering may be one way to introduce EPA synthesis into cyanobacteria.

Cyanobacterial genetic engineering has been developed mainly with freshwater strains, such as Synechocystis, Synechococcus and Anabaena, to elucidate their photosynthesis mechanisms (Golden, 1994; Xu et al., 1995), nitrogen fixation (Golden et al., 1991; Lyons \& Thiel, 1995) and morphological differentiation (Wolk, 1991; Wolk et al., 1993). Many marine cyanobacteria have been screened and some have been found to produce useful materials such as UV-absorbing material (Matsunaga et al., 1993; Wachi et al., 1995a), plant growth regulators (Wake et al., 1992), melanin biosynthesis inhibitors (Wachi et al., 1995b) and antimicrobial compounds (Miura et al., 1993). Genetic manipulation has been considered as a promising technique to enhance production of these substances. However, since the useful strains were not naturally transformable, several gene transfer experiments were carried out as the first step torwards genetic engineering of these strains. Transfer by electroporation and conjugation has been established in marine cyanobacteria (Matsunaga et al., 1990; Sode et al., 1992; Matsunaga \& Takeyama, 1995; Brahamsha, 1996) and a high-copy-number plasmid was 

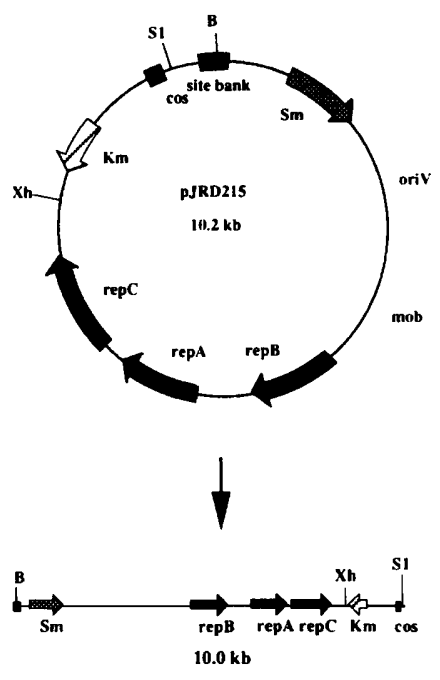

$\underset{\substack{\mathrm{Km} \cos \\ 1.8 \mathrm{~kb}}}{\mathrm{Kh}}$
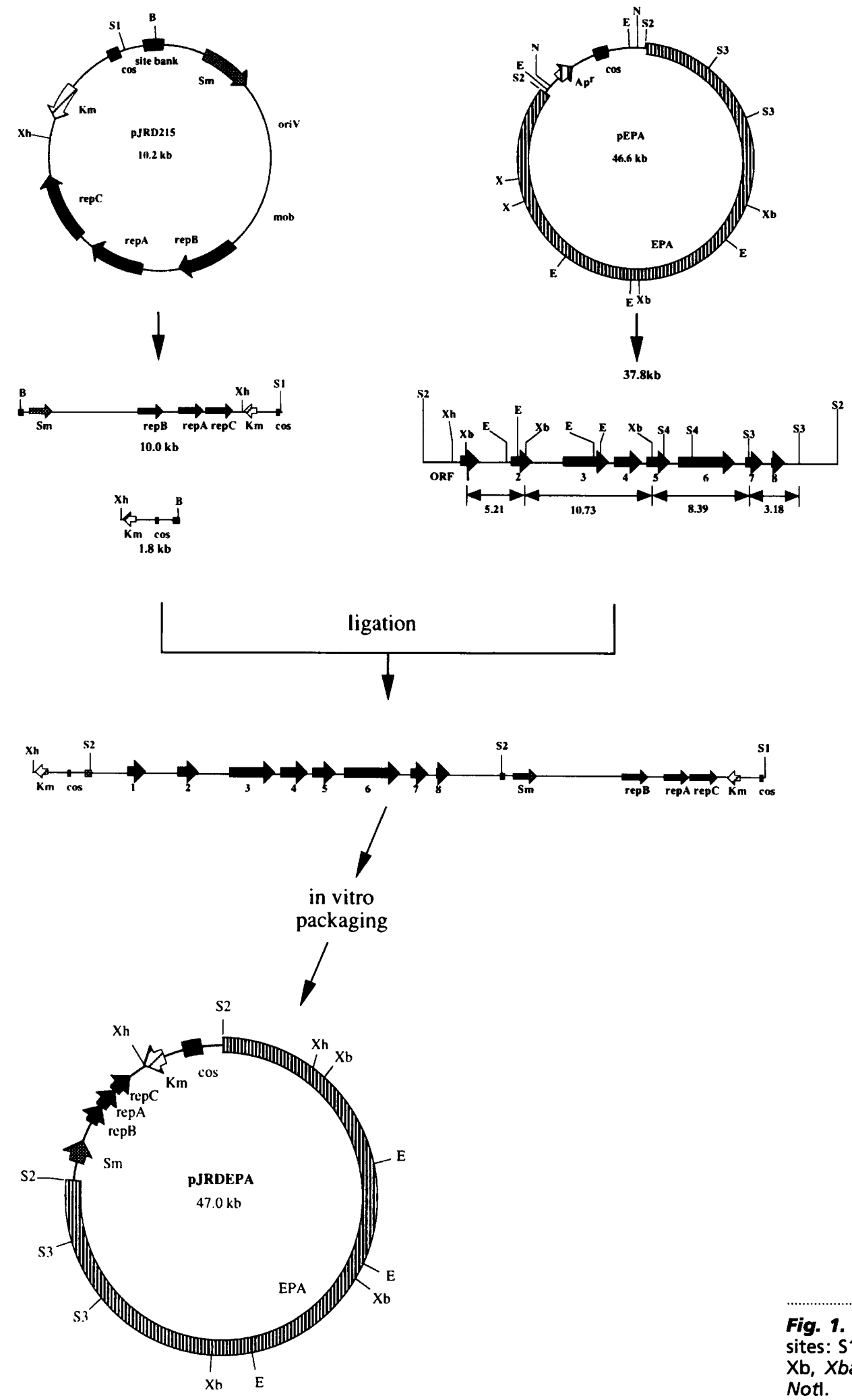

Fig. 1. Construction of pJRDEPA. Restriction sites: S1, Sall; S2, Sau3Al; S3, Spel; S4, Sphl; Xb, Xbal; Xh, Xhol; E, ECoRl; B, BamHl; N, Notl.

found in a marine Synechococcus sp. (Takeyama et al., 1991). Hence, metabolic engineering, which is defined as the genetic modification of metabolic pathways to produce new products, can be applied to certain marine cyanobacterial strains.
Several desaturase genes have been isolated from freshwater cyanobacteria (Wada et al., 1990; Sakamoto et al., 1994a, b). The des $A$ gene ( $\Delta^{12}$ desaturase gene) was isolated from Synechocystis PCC 6803 and expressed in Synechococcus sp. PCC 7942; it resulted in a change of 
fatty acid composition and enhancement of chilling tolerance of the latter strain (Wada et al., 1990). On the other hand, elongation genes for fatty acid synthesis have not been isolated. Yazawa et al. (1988) isolated a marine bacterium, Shewanella sp. SCRC-2738, from fish intestines that produced EPA. The EPA synthesis gene cluster (approx. $38 \mathrm{~kb}$ ) was isolated from this strain (Yazawa, 1996); it comprised eight open reading frames (ORFs). Three of the ORFs showed similarities with genes encoding enzymes which related to de novo synthesis of fatty acids or to carbon chain elongation. Since EPA was produced in Escherichia coli into which the EPA synthesis gene cluster was cloned, it was speculated that desaturase genes were included in the remaining ORFs (Yazawa, 1996).

In this paper, we describe metabolic engineering of a marine cyanobacterium by expressing a large gene cluster from Shewanella sp. SCRC-2738 in Synechococcus sp., and demonstrate the effect of temperature conditions on EPA synthesis in marine cyanobacterial cells.

\section{METHODS}

Strains and plasmids. A marine cyanobacterium, Synechococcus sp. NKBG042902, isolated from a Japanese coastal area was used as a host strain (Takano et al., 1992). It was cultured in BG 11 medium (ATCC catalogue, medium no. 617) supplemented with $3 \% \mathrm{NaCl}$, under aerobic conditions at 29 or $23{ }^{\circ} \mathrm{C}$ with a light intensity of $50 \mu \mathrm{E} \mathrm{m} \mathrm{m}^{-2} \mathrm{~s}^{-1}$. Escherichia coli S17-1 (Simon et al., 1983) and NM554 (Raleigh et al., 1988) were cultured under aerobic conditions using LB medium (bact-tryptone $10 \mathrm{~g} \mathrm{l}^{-1}$, bact-yeast extract $5 \mathrm{~g} \mathrm{l}^{-1}$ and $\left.\mathrm{NaCl} 3 \mathrm{~g} \mathrm{l}^{-1} ; \mathrm{pH} 7 \cdot 4\right)$ at 37 or $20^{\circ} \mathrm{C}$. The broadhost-range vector plasmids pJRD215 $\left(10.2 \mathrm{~kb}, \mathrm{Km}^{\mathrm{r}} \mathrm{Sm}^{\mathrm{r}}\right)$ (Davison et al., 1987) and pKT230 (10.2 kb, Km ${ }^{\mathrm{r}} \mathrm{Sm}^{\mathrm{r}}$ ) (Bagdasarian et al., 1981) were used. pEPA (Yazawa, 1996) consisted of pWE15 and the EPA synthesis gene cluster (GenBank accession number U73935) isolated from Shewanella putrefaciens SCRC-2738.

Construction of plasmid for expression of EPA synthesis genes. Fig. 1 shows the construction of a plasmid containing the EPA synthesis gene cluster in the vector pJRD215. The EPA synthesis gene cluster (approx. $38 \mathrm{~kb}$ ) was excised from pEPA by Sau3AI digestion. pJRD215 was digested with Sal I or XhoI, and the linear vector DNAs were cleaved with $B a m \mathrm{HI}$. The two vector fragments containing cos sequence were isolated and ligated to the EPA synthesis gene cluster generated by digestion with Sau3AI. This concatemer was packaged in vitro to bacteriophage lambda particles using an in vitro packaging kit (Gigapack II Packaging Extracts, Stratagene) and used to infect $E$. coli NM554. Infected cells were plated onto LB medium plates containing $50 \mu \mathrm{g}$ kanamycin $\mathrm{ml}^{-1}$.

Conjugal gene transfer of cyanobacterium. Cyanobacterial cells in mid-exponential phase were centrifuged, washed with BG11 marine medium, and resuspended in fresh medium. Freshly transformed E. coli S17-1 with pJRD215, pKT230 or cosmids isolated from transfected $E$. coli NM554 were collected from LB plates and resuspended in BG11 marine medium. Suspensions of cyanobacterial cells and transformed E. coli cells were mixed at a cell number ratio of $1: 10$ (cyanobacterium : E. coli) and spotted onto dried BG11 marine medium agar plates. After $48 \mathrm{~h}$ incubation under light, the collected cell mixtures were subjected to selection of cyanobacterial transconjugants on the BG11 marine agar plates containing $25 \mu \mathrm{g}$ kanamycin $\mathrm{ml}^{-1}$.

Fatty acid analysis. Cyanobacteria or E. coli cells in lateexponential phase were centrifuged at $6000 \mathrm{~g}$ and $4{ }^{\circ} \mathrm{C}$, washed

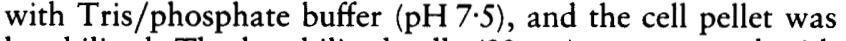
lyophilized. The lyophilized cells $(30 \mathrm{mg})$ were treated with $2 \mathrm{ml} \mathrm{5 \%}$ methanolic hydrochloride acid (Kokusan Co.) including pentadecanoic acid (C15:0) as a internal standard, and heated at $90^{\circ} \mathrm{C}$ for $40 \mathrm{~min}$. After the samples had cooled down, they were diluted with $1 \mathrm{ml} \mathrm{H}_{2} \mathrm{O}$ and extracted with $1 \mathrm{ml} \mathrm{n}$-hexane. The collected hexane layer, in which methyl esters of fatty acids were partitioned, was dried and redissolved in $\mathbf{n}$-hexane. Fatty acid methyl esters were analysed by gas chromatography (GC-14B, Shimadzu) with a capillary column (HR-Thermon 300B, $0.25 \mathrm{~mm} \times 25 \mathrm{~m}$, Shinwa Chemical Industries). The injection temperature was $250^{\circ} \mathrm{C}$. The column temperature was programmed to increase from 180 to $220^{\circ} \mathrm{C}\left(180^{\circ} \mathrm{C}\right.$ for $1 \mathrm{~min}$, then increasing by $1^{\circ} \mathrm{C} \mathrm{min}^{-1}$ to $190^{\circ} \mathrm{C}, 190^{\circ} \mathrm{C}$ for $2 \mathrm{~min}$, then increasing by $5^{\circ} \mathrm{C} \mathrm{min}^{-1}$ to $210^{\circ} \mathrm{C}, 210^{\circ} \mathrm{C}$ for $15 \mathrm{~min}$, then increasing by $15^{\circ} \mathrm{C} \mathrm{min}{ }^{-1}$ to $220^{\circ} \mathrm{C}, 220^{\circ} \mathrm{C}$ for $5 \mathrm{~min}$ ). The quantities of fatty acids were estimated from the peak areas on the chromatogram using the internal standard by C-RA6A Chromatopac (Shimadzu).

Southern hybridization analysis. Southern hybridization analysis of plasmids was carried out using as a probe a $3 \cdot 2 \mathrm{~kb}$ fragment including ORF8 that was labelled with the DIG chemiluminescence kit (Boehringer Mannheim). Plasmids were extracted from $E$. coli by a standard method (Sambrook et al., 1989).

Evaluation of plasmid stability in cyanobacterial cells. The stability of plasmids was evaluated as the ratio of cells harbouring the plasmid to total cells. Cell samples were collected at several times during the growth of cyanobacterial transconjugants in BG11 marine medium containing kanamycin $\left(25 \mu \mathrm{g} \mathrm{ml}^{-1}\right)$, and were plated out on BG11 marine medium with or without kanamycin. The ratio of cells harbouring the plasmid was calculated as the number of colonies on plates with kanamycin divided by the number of colonies on plates without kanamycin.

GC-MS analysis of gene product. Fatty acid methyl esters extracted from transformed cells were separated on TLC silica gel impregnated with silver nitrate in n-hexane/ether $(80: 20)$ into several fatty acid groups. Groups of unsaturated fatty acid methyl esters with more than three double bonds were identified by comparison with standards. They were extracted from TLC plates and subjected to GC-MS analysis using a Hitachi GC-mass spectrometer (M-80A) with a capillary column (DB-WAX, 0.32 mm $\times 30 \mathrm{~m}$; J \& W Scientific). The injection and column temperature were $220^{\circ} \mathrm{C}$ and $250^{\circ} \mathrm{C}$, respectively. The temperature was programmed to increase from 80 to $240^{\circ} \mathrm{C}\left(80^{\circ} \mathrm{C}\right.$ for $1 \mathrm{~min}$, then increasing by $20^{\circ} \mathrm{C}$ $\mathrm{min}^{-1}$ to $180^{\circ} \mathrm{C}, 180^{\circ} \mathrm{C}$ for $5 \mathrm{~min}$, then increasing by $5^{\circ} \mathrm{C} \min ^{-1}$ to $190^{\circ} \mathrm{C}, 190^{\circ} \mathrm{C}$ for $5 \mathrm{~min}$, then increasing by $5^{\circ} \mathrm{C} \mathrm{min}^{-1}$ to $240^{\circ} \mathrm{C}, 240^{\circ} \mathrm{C}$ for $20 \mathrm{~min}$ ).

\section{RESULTS}

\section{Construction of a plasmid containing an EPA synthesis gene cluster and EPA production in E. coli}

Since a broad-host-range cosmid vector for Gramnegative bacteria, pJRD215, was confirmed to replicate in the marine cyanobacterium Synechococcus sp. 


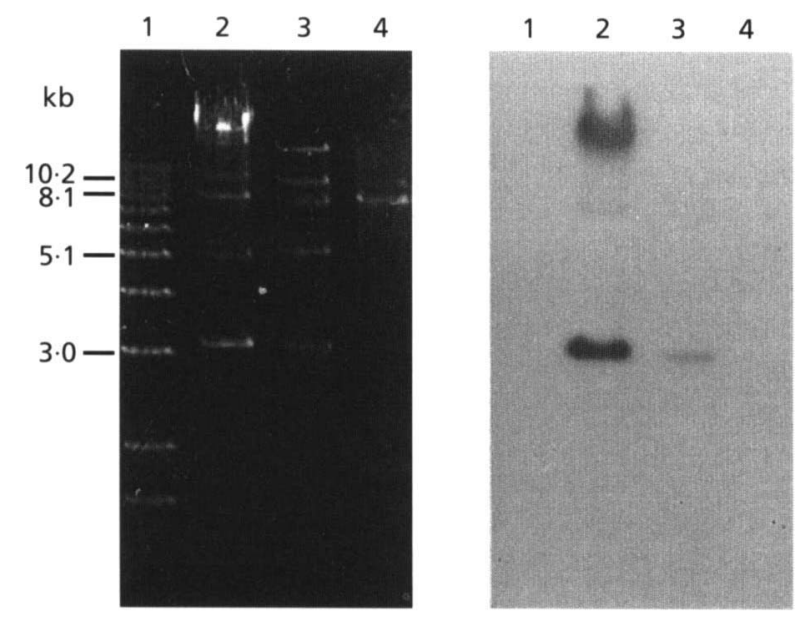

Fig. 2. Southern hybridization analysis of a plasmid harboured by exconjugant E2 using a $3.2 \mathrm{~kb}$ fragment (ORF8) as a probe. Lane 1, $1 \mathrm{~kb}$ ladder; lane 2, pEPA digested with $X$ bal and Spel; lane 3 , the constructed plasmid from $E$. coli E2 digested with $X$ bal and Spel; lane 4, pJRD215.

NKBG042902 during preliminary experiments, this vector was used to clone an EPA synthesis gene cluster into the cyanobacterial host. To select the transconjugants of E. coli NM554 having the EPA synthesis gene cluster, plasmids extracted from the $E$. coli transconjugants were digested with $\mathrm{XbaI}$ and SpeI. Among 35 transconjugants resistant to kanamycin, the plasmids of three transconjugants, E1, E2 and E3, showed the same restriction pattern as that of $\mathrm{pEPA}$. As EPA production was affected by growth temperature, EPA production by these three transconjugants grown at $20^{\circ} \mathrm{C}$ was measured according to the previous report (Yazawa, 1996). Transconjugants E1 and E2 produced larger amounts of EPA $\left[3.2 \pm 0.7\right.$ and $\left.3.3 \pm 0.7 \mathrm{mg}(\mathrm{g} \text { dry weight })^{-1}\right]$ than transconjugant E3 $\left.[0 \cdot 3 \pm 0 \cdot 1 \mathrm{mg} \text { (g dry weight })^{-1}\right]$. E1 and E2 may have a plasmid harbouring the intact EPA synthesis gene cluster. Fig. 2 shows the restriction pattern of the plasmid from E2 and pEPA restricted with $X b a \mathrm{I}$ and SpeI, and the result of Southern hybridization analysis. pEPA and the constructed plasmid appeared to share four fragments identical to those from the EPA synthesis gene cluster. The fragment including ORF8 hybridized to the $3.2 \mathrm{~kb}$ fragment from both plasmids. The plasmid in E. coli E2 was designated pJRDEPA and was used for further experiments.

\section{Transconjugation of Synechococcus sp.}

Plasmids pJRDEPA (approx. $48 \mathrm{~kb}$ ) and pJRD215 $(10 \cdot 2 \mathrm{~kb})$ were transferred to Synechococcus sp. NKBG042902 by conjugation. For comparison, another broad-host-range vector plasmid, pKT230 (11.9 kb), was also used in a gene transfer experiment. The transconjugation efficiencies of pKT230, pJRD215 and pJRDEPA in cyanobacterial cells were $2.3 \times 10^{-6}$, $3.3 \times 10^{-6}$ and $2 \cdot 2 \times 10^{-7}$ transconjugants per recipient cell, respectively.

Table 1. Fatty acid composition of wild-type Synechococcus sp. NKBG042902 and a transconjugant harbouring pJRDEPA, grown at different temperatures

\begin{tabular}{|c|c|c|c|c|c|c|}
\hline \multirow{3}{*}{$\begin{array}{l}\text { Fatty acid } \\
\text { composition }\end{array}$} & \multicolumn{6}{|c|}{ Fatty acid content (weight percentage of total fatty acids) } \\
\hline & \multicolumn{3}{|c|}{ Wild-type } & \multicolumn{3}{|c|}{ Transconjugant } \\
\hline & $29^{\circ} \mathrm{C}$ & $23^{\circ} \mathrm{C}$ & $23^{\circ} \mathrm{C}$ to $17^{\circ} \mathrm{C}^{*}$ & $29^{\circ} \mathrm{C}$ & $23^{\circ} \mathrm{C}$ & $23^{\circ} \mathrm{C}$ to $17^{\circ} \mathrm{C}^{*}$ \\
\hline less than $15: 0$ & $14 \cdot 0 \pm 0 \cdot 4$ & $14 \cdot 2 \pm 0 \cdot 4$ & $14 \cdot 1 \pm 0 \cdot 8$ & $14 \cdot 1 \pm 0 \cdot 3$ & $14 \cdot 3 \pm 0 \cdot 7$ & $10 \cdot 4 \pm 1 \cdot 1$ \\
\hline $16: 0$ & $37 \cdot 5 \pm 0 \cdot 3$ & $32 \cdot 4 \pm 0.7$ & $32 \cdot 3 \pm 1 \cdot 7$ & $32.9 \pm 0.9$ & $31 \cdot 4 \pm 0 \cdot 8$ & $34 \cdot 8 \pm 1 \cdot 4$ \\
\hline $16: 1$ & $7 \cdot 5 \pm 0 \cdot 1$ & $8 \cdot 8 \pm 0 \cdot 4$ & $11 \cdot 7 \pm 0.5$ & $9.6 \pm 0.6$ & $9 \cdot 1 \pm 0 \cdot 2$ & $10 \cdot 7 \pm 0 \cdot 7$ \\
\hline $17: 0$ & $0 \cdot 3 \pm 0 \cdot 0$ & $0 \cdot 3 \pm 0 \cdot 0$ & $0 \cdot 3 \pm 0 \cdot 0$ & $0 \cdot 3 \pm 0 \cdot 0$ & $0 \cdot 3 \pm 0 \cdot 0$ & $0 \cdot 4 \pm 0 \cdot 0$ \\
\hline $17: 1$ & $1 \cdot 1 \pm 0 \cdot 0$ & $1 \cdot 3 \pm 0 \cdot 1$ & $1 \cdot 3 \pm 0 \cdot 1$ & $1 \cdot 3 \pm 0 \cdot 0$ & $1 \cdot 3 \pm 0 \cdot 1$ & $1 \cdot 3 \pm 0 \cdot 1$ \\
\hline $18: 0$ & $1 \cdot 4 \pm 0 \cdot 0$ & $1 \cdot 3 \pm 0 \cdot 1$ & $1 \cdot 0 \pm 0 \cdot 1$ & $1 \cdot 32 \pm 0 \cdot 1$ & $1.4 \pm 0.0$ & $1.5 \pm 0.3$ \\
\hline $18: 1$ & $20 \cdot 7 \pm 0 \cdot 3$ & $26 \cdot 0 \pm 2 \cdot 1$ & $20 \cdot 6 \pm 0.6$ & $25 \cdot 1 \pm 0 \cdot 8$ & $23 \cdot 7 \pm 1.9$ & $21 \cdot 5 \pm 5 \cdot 3$ \\
\hline $18: 2$ & $7 \cdot 8 \pm 0 \cdot 1$ & $5 \cdot 3 \pm 0 \cdot 9$ & $7 \cdot 2 \pm 0 \cdot 8$ & $5 \cdot 7 \pm 0 \cdot 2$ & $5 \cdot 4 \pm 0.4$ & $5 \cdot 4 \pm 0 \cdot 2$ \\
\hline $18: 3 \gamma$ & $0 \cdot 2 \pm 0 \cdot 0$ & $0 \cdot 3 \pm 0 \cdot 1$ & $0 \cdot 3 \pm 0 \cdot 0$ & $0 \cdot 4 \pm 0 \cdot 1$ & $0.4 \pm 0.0$ & $0 \cdot 4 \pm 0 \cdot 1$ \\
\hline $18: 3 \alpha$ & $4 \cdot 4 \pm 0 \cdot 1$ & $4 \cdot 4 \pm 0 \cdot 4$ & $6 \cdot 4 \pm 0 \cdot 2$ & $5 \cdot 0 \pm 0 \cdot 2$ & $4 \cdot 4 \pm 0 \cdot 2$ & $4 \cdot 5 \pm 0 \cdot 7$ \\
\hline $20: 0$ & trace & trace & trace & trace & trace & trace \\
\hline $20: 2$ & $0 \cdot 3 \pm 0 \cdot 0$ & $0 \cdot 3 \pm 0 \cdot 0$ & $0 \cdot 4 \pm 0.0$ & $4 \cdot 0 \pm 0 \cdot 1$ & $0.6 \pm 0.1$ & $0 \cdot 6 \pm 0 \cdot 2$ \\
\hline $20: 3$ & $0 \cdot 4 \pm 0 \cdot 1$ & $0 \cdot 3 \pm 0 \cdot 0$ & $0 \cdot 5 \pm 0 \cdot 1$ & $0 \cdot 5 \pm 0 \cdot 1$ & $0 \cdot 4 \pm 0 \cdot 3$ & $0 \cdot 7 \pm 0 \cdot 1$ \\
\hline $20: 4$ & - & - & - & trace & trace & trace \\
\hline $20: 5(\mathrm{EPA})$ & - & - & - & $\leqslant 0 \cdot 1$ & $0.4 \pm 0.3$ & $0.5 \pm 0.2$ \\
\hline Others & $4 \cdot 4 \pm 0.8$ & $4 \cdot 7 \pm 1 \cdot 7$ & $4 \cdot 0 \pm 0.5$ & $3 \cdot 3 \pm 0 \cdot 7$ & $9 \cdot 3 \pm 1 \cdot 2$ & $10 \cdot 7 \pm 3 \cdot 4$ \\
\hline
\end{tabular}

trace, $<0 \cdot 05 ;-$, not detected.

*Cells grown at $23^{\circ} \mathrm{C}$ were incubated for $1 \mathrm{~d}$ at $17^{\circ} \mathrm{C}$ under light and aerobic conditions. 


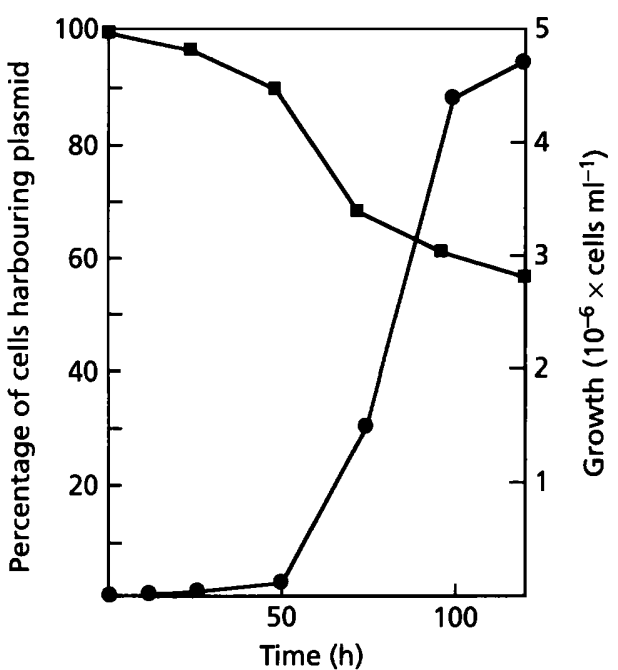

Fig. 3. Ratio of cells harbouring plasmid pJRDEPA $\left(\mathrm{Km}^{\prime}\right)$ to total cells ( $\mathbb{a}$ ) and growth curve of the cyanobacterial transconjugant (O).

\section{EPA production in cyanobacterial cells}

The cyanobacterial transconjugant harbouring pJRDEPA was cultured at several growth temperatures. Table 1 shows the fatty acid compositions of the transconjugant and wild-type Synechococcus sp. NKBG042902 grown at 29 and $23^{\circ} \mathrm{C}$, and at a culture temperature of $23^{\circ} \mathrm{C}$ but transferred to $17^{\circ} \mathrm{C}$ for $1 \mathrm{~d}$ before fatty acids were analysed. There was no apparent difference in the fatty acid composition between the wild-type and transconjugant. EPA production was not detected in the wild-type, whereas cyanobacterial transconjugants harbouring pJRDEPA produced EPA. The transconjugant grown at $23{ }^{\circ} \mathrm{C}$ appeared to have a higher EPA content $[0.4 \pm 0.3 \% ; 0.56 \pm 0.37 \mathrm{mg}$ (g dry weight $)^{-1}$ ] than that grown at $29^{\circ} \mathrm{C} \quad(\leqslant 0 \cdot 1 \%$; $\leqslant 0.12 \mathrm{mg}$ (g dry weight $\left.)^{-1}\right]$. The highest amount of EPA was produced when the temperature was lowered to $17^{\circ} \mathrm{C}$ for $1 \mathrm{~d}$ under light and aeration $\left[0.5 \pm 0.2 \% ; 0.64 \pm 0.27 \mathrm{mg}\right.$ (g dry weight) $\left.{ }^{-1}\right]$.

\section{Stability of plasmid in cyanobacterial cells}

Fig. 3 shows the growth curve of the cyanobacterial transconjugant harbouring pJRDEPA at $23^{\circ} \mathrm{C}$ and the loss of this plasmid during growth. The ratio of cells harbouring pJRDEPA to total cells decreased from an initial value of almost $100 \%$ to $58 \%$ in the stationary phase $\left(4.8 \times 10^{6}\right.$ cells ml $\left.^{-1}\right)$.

\section{GC-MS analysis of EPA produced by Synechococcus sp. harbouring pJRDEPA}

EPA produced by E. coli and the cyanobacterial transconjugant that was identified by gas chromatography analysis was further characterized by mass spectral analysis (Fig. 4). Both organisms produced a substance detected at $m / z 316$ that corresponds to the molecular mass of EPA. An ion peak typically detected in highly unsaturated fatty acid at $m / z 79$ was also present. These results indicate that the product was EPA.

\section{DISCUSSION}

Transconjugation using a cosmid vector with an origin of replication from a Nostoc sp. plasmid was reported in the freshwater filamentous cyanobacterium Anabaena sp. PCC 7120 and in Synechococcus sp. PCC 7920 (Wolk et al., 1988; Vega-Palas et al., 1990; Buikema \& (a)
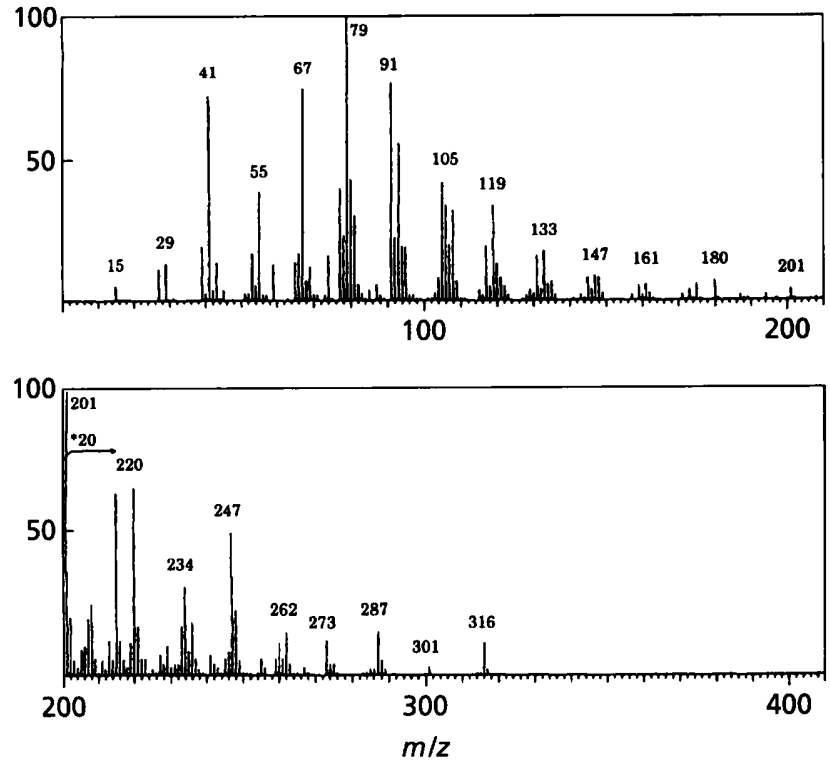

(b)
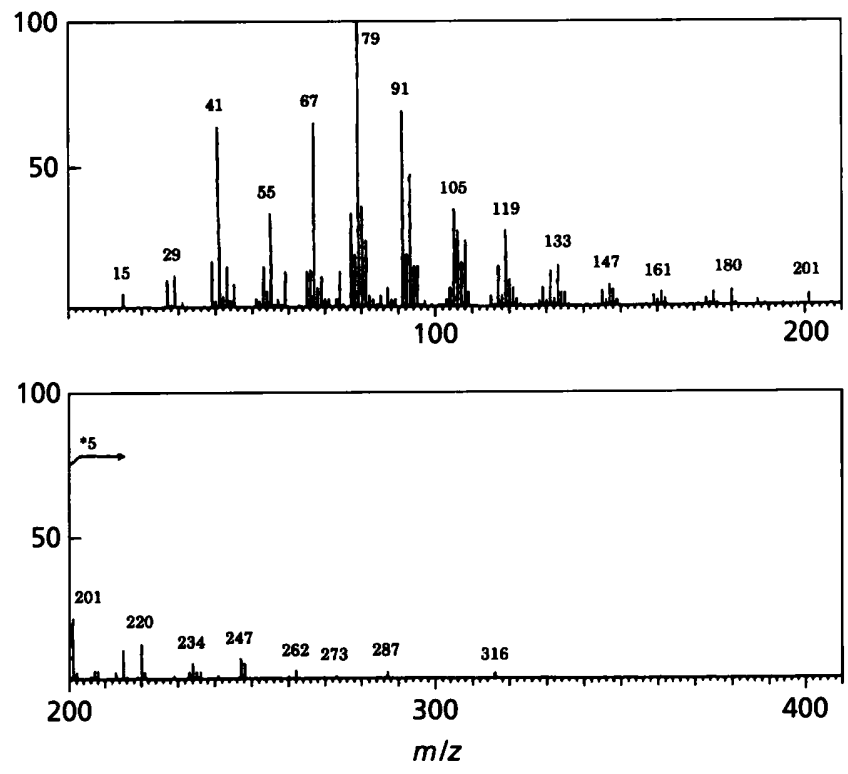

Fig. 4. Mass chromatograms of EPA produced by E. coli (a) and the cyanobacterial transconjugant (b). 
Haselkorn, 1991). In these studies, however, only small fragments were cloned and successfully transferred to the host. Furthermore, these experiments were carried out for the purpose of gene isolation. In the present study, a very large gene cluster encoding proteins required in EPA synthesis was introduced into and expressed in the marine cyanobacterium Synechococcus sp., which normally produced unsaturated fatty acids only up to $\mathrm{C} 18: 3$. This result should lead to further investigations on the cloning and expression of genes encoding enzymes comprising multiple subunits. Since deletion of any ORF in the EPA synthesis gene cluster cloned into E. coli resulted in lack of EPA production as well as absence of intermediate products (Yazawa, 1996), it is not clear which fatty acid was used for EPA synthesis. Accordingly, few differences were observed in the fatty acid composition of the cyanobacterial transconjugant and the wild-type. Yazawa (1996) showed that EPA production in E. coli was higher at a lower temperature than the optimum growth temperature; this finding is corroborated by our results with transconjugants of Synechococcus sp.

Plasmid pEPA possesses T3 and T7 promoters upstream of the EPA synthesis gene cluster, but pJRDEPA does not. Nevertheless, EPA production in E. coli harbouring pEPA was not higher than that in E. coli harbouring pJRDEPA. These results strongly suggest that the EPA synthesis genes contain their own promoters which work in E. coli and in cyanobacterial cells. However, the amount of EPA produced by the cyanobacterial transconjugant was much lower than that of $E$. coli. One reason may be a lower copy number of the broad-hostrange cosmid vector in the cyanobacterium as compared to E. coli. The copy number of pJRD215 was estimated to be less than five per cyanobacterial cell (data not shown), and that of the $48 \mathrm{~kb}$ pJRDEPA must be even lower. Furthermore, plasmid replication of very large cosmids may not follow cell division, and cells without plasmids may already have been enriched when cells were extracted for EPA analysis. Introduction of a cyanobacterial replication region to a cosmid vector might enhance the stability of the transferred plasmid, consequently increasing EPA production.

\section{ACKNOWLEDGEMENTS}

We thank Dr J. G. Burgess of Heriot-Watt University for reading this manuscript.

\section{REFERENCES}

Abbey, M., Clifton, P., Kestin, M., Belling, B. \& Nestel, P. (1990). Effect of fish oil on lipoproteins, lecithin:cholesterol acyltransferase, and lipid transfer protein activity in humans. Arteriosclerosis 10, 85-94.

Bagdasarian, M., Lurz, R., Ruckert, B., Franklin, F. H. C., Bagdasarian, M. M., Frey, J. \& Timmis, K. N. (1981). Specific-purpose plasmid cloning vectors. II. Broad host range, high copy number, RSF1010-derived vectors, and a host-vector system for gene cloning in Pseudomonas. Gene 16, 237-247.

Brahamsha, B. (1996). A genetic manipulation system for oceanic cyanobacteria of the genus Synechococcus. Appl Environ Microbiol 62, 1747-1751.

Buikema, W. J. \& Haselkorn, R. (1991). Isolation and complementation of nitrogen fixation mutants of the cyanobacterium Anabaena sp. strain PCC 7120. J Bacteriol 173, 1879-1885.

Cohen, Z., Norman, H. A. \& Heimer, Y. M. (1995). Microalgae as a source of $\omega 3$ fatty acids. In Plants in Human Nutrition (World Review of Nutrition and Dietetics, vol. 77), pp. 1-31. Edited by A. P. Simopoulos. Basel : Karger.

Davison, J., Heusterspreute, M., Chevalier, N., Ha-Thi, V. \& Brunel, F. (1987). Vectors with restriction site banks. V. pJRD215, a wide-host-range cosmid vector with multiple cloning sites. Gene 51, 275-280.

Golden, J. W., Whorff, L. L. \& Wiest, D. R. (1991). Independent regulation of nifHDK operon transcription and DNA rearrangement during heterocyst differentiation in the cyanobacterium Anabaena sp. strain PCC7120. J Bacteriol 173, 7098-7105.

Golden, S. S. (1994). Light-responsive gene expression and the biochemistry of the photosystem II reaction center. In The Molecular Biology of Cyanobacteria, pp. 693-714 Edited by D. A. Bryant. Dordrecht: Kluwer.

Lyons, E. M. \& Thiel, T. (1995). Characterization of nifB, nifS, and nifU genes in the cyanobacterium Anabaena variabilis: NifB is required for the vanadium-dependent nitrogenase. $J$ Bacteriol 177, 1570-1570.

Matsunaga, T. \& Takeyama, H. (1995). Genetic engineering in marine cyanobacteria. J Appl Phycol 7, 77-84.

Matsunaga, T., Takeyama, H. \& Nakamura, N. (1990). Characterization of cryptic plasmids from marine cyanobacteria and construction of a hybrid plasmid potentially capable of transformation of marine cyanobacterium, Synechococcus sp., and its transformation. Appl Biochem Biotechnol 24/25, 151-160.

Matsunaga, T., Burgess, J. G., Yamada, N., Komatsu, K., Yoshida, S. \& Wachi, Y. (1993). An ultraviolet (UV-A) absorbing biopterin glucoside from the marine planktonic cyanobacterium Oscillatoria sp. Appl Microbiol Biotechnol 39, 250-253.

Miura, Y., Sode, K., Narasaki, Y. \& Matsunaga, T. (1993). Lightinduced antimicrobial activity of extracts from marine Chlorella. J Mar Biotechnol 1, 143-146.

Needleman, P., Raz, A., Minkes, M. S., Ferrendelli, J. A. \& Sprecher, H. (1979). Triene prostaglandins: prostacyclin and thromboxane biosynthesis and unique biological properties. Proc Natl Acad Sci USA 76, 944-948.

Raleigh, E. A., Murray, N. E., Revel, H., Blumenthal, R. M., Westaway, D., Reith, A. D., Rigby, P. W. J., Elhai, J. \& Hanahan, D. (1988). McrA and McrB restriction phenotypes of some E. coli strains and implications for gene cloning. Nucleic Acids Res 16, 1563-1563.

Sakamoto, T., Los, D. A., Higashi, S., Wada, H., Nishida, I., Ohmori, M. \& Murata, N. (1994a). Cloning of omega 3 desaturase from cyanobacteria and its use in altering the degree of membrane-lipid unsaturation. Plant Mol Biol 26, 249-263.

Sakamoto, T., Wada, H., Nishida, I., Ohmori, M. \& Murata, N. (1994b). Identification of conserved domains in the delta 12 desaturase of cyanobacteria. Plant Mol Biol 24, 643-650.

Sambrook, J., Fritsch, E. F. \& Maniatis, T. (1989). In Molecular Cloning: a Laboratory Manual, 2nd edn, pp. 21-39. Cold Spring Harbor, NY: Cold Spring Harbor Laboratory.

Simon, R., Priefer, U. \& Puhler, A. (1983). A broad host range mobilization system for in vivo genetic engineering: transposon mutagenesis in Gram negative bacteria. Bio/Technology 118, 640-659. 
Sode, K., Tatara, M., Takeyama, M., Burgess, J. G. \& Matsunaga, T. (1992). Conjugative gene transfer in marine cyanobacteria: Synechococcus sp., Synechocystis sp. and Pseudanabaena sp. Appl Microbiol Biotechnol 37, 369-373.

Takano, H., Takeyama, H., Nakamura, N., Sode, K., Burgess, J. G., Manabe, E., Hirano, M. \& Matsunaga, T. (1992). $\mathrm{CO}_{2}$ removal by high density culture of a marine cyanobacterium Synechococcus sp. using an improved photobioreacter employing light-diffusing optical fibers. Appl Biochem Biotechnol 34/35, 449-458.

Takeyama, H., Burgess, J. G., Sode, K. \& Matsunaga, T. (1991). Salinity dependent copy number increase of a marine cyanobacterial endogenous plasmid. FEMS Microbiol Lett 90, 95-98.

Terano, T., Salmon, J. A. \& Moncada, S. (1984). Effect of orally administered eicosapentaenoic acid (EPA) on the formation of leukotriene $\mathrm{B}_{4}$ and leukotriene $\mathrm{B}_{5}$ by rat leukocytes. Prostaglandins 27, 217-232.

Vega-Palas, M. A., Madueno, F., Herrero, A. \& Flores, E. (1990). Identification and cloning of a regulatory gene for nitrogen assimilation in the cyanobacterium Synechococcus sp. strain PCC 7942. J Bacteriol 172, 643-647.

Viso, A. C. \& Marty, J. C. (1993). Fatty acids from 23 marine microalgae. Phytochemistry 34, 1521-1533.

Wachi, Y., Burgess, J. B., Iwamoto, K., Yamada, N., Nakamura, N. \& Matsunaga, T. (1995a). Effect of ultraviolet-A (UV-A) light on growth, photosynthetic activity and production of biopterin glucoside by the marine UV-A resistant cyanobacterium Oscillatoria sp. Biochim Biophys Acta 1244, 165-168.

Wachi, Y., Sode, K., Horikoshi, K., Takeyama, H. \& Matsunaga, T. (1995b). Screening of melanin biosynthesis inhibitors from marine microalgae using Streptomyces bikiniensis bioassay. Biotechnol Techniques 9, 633-636.
Wada, H., Gombos, Z. \& Murata, N. (1990). Enhancement of chilling tolerance of a cyanobacterium by genetic manipulation of fatty acid desaturation. Nature 347, 200-203.

Wake, H., Akasaka, A., Umetsu, H., Ozeki, Y., Shimomura, K. \& Matsunaga, T. (1992). Enhanced germination of artificial seeds by marine cyanobacterial extract. Appl Microbiol Biotechnol 36, $684-688$.

Wolk, C. P. (1991). Genetic analysis of cyanobacterial development. Curr Opin Genet Dev 1, 336-341.

Wolk, C. P., Cai, Y., Cardemil, L., Flores, E., Hohn, B., Murry, M., Schmetterer, G., Schrautemeier, B. \& Wilson, R. (1988). Isolation and complimentation of mutant of Anabaena sp. strain PCC 7120 unable to grow aerobically on dinitrogen. J Bacteriol 170, $1239-1244$

Wolk, C. P., Elhai, J., Kuritz, T. \& Holland, D. (1993). Amplified expression of a transcriptional pattern formed during development of Anabaena. Mol Microbiol 7, 441-445.

Xu, Q., Hoppe, D., Chitnis, V. P., Odam, W. R., Guikema, J. A. \& Chitnis, P. R. (1995). Mutational analysis of photosystem I polypeptides in the cyanobacterium Synechocystis sp. PCC6903. Targeted inactivation of $p s a l$ reveals the function of $p s a l$ in the structural organization of psaL. J Biol Chem 270, 16243-16250.

Yazawa, K. (1996). Production of eicosapentaenoic acid from marine bacteria. Lipids 31, S297-S300.

Yazawa, K., Araki, K., Watanabe, K., Ishikawa, C., Inoue, A. Kondo, K., Watabe, S. \& Hashimoto, K. (1988). Eicosapentaenoic acid productivity of the bacteria isolated from fish intestines. Nippon Suisan Gakkaishi 54, 1835-1838.

Received 9 December 1996; revised 13 April 1997; accepted 14 April 1997. 